\title{
Terapi Musik Rebana Mampu Meningkatkan Kualitas Tidur Lansia
}

\author{
Iskim Luthfa ${ }^{1}$, Moch. Aspihan ${ }^{2}$ \\ ${ }^{1,2}$ Fakultas Keperawatan, Universitas Islam Sultan Agung Semarang \\ Email: iskimluthfa@unissula.ac.id
}

\begin{abstract}
Rebana Music Therapy Able to Improve Quality of Elderly Sleep. Sleep is a basic human need that must be met. The need for sleep in the elderly ranges from 5-6 hours per day. However, changes in body condition, physical and psychological health problems cause elderly at risk of sleep disorders. Non-pharmacological interventions to overcome sleep disorders in the elderly one of them by using music rebana. The use of rebana music as a therapy is similar to occupational and physical therapy, able to stimulate the body to release epinephrine and norepinephrine that make the body relax. This relaxed condition will improve the quality of elderly sleep. The purpose of this study was to prove the use of music rebana as a therapy that can improve the quality of sleep in the elderly. This research method was quasi-experiment with the design of nonequivalent control group. The sample of this study was 56 elderly living in the Pucang Gading Seni Social Service Unit of Semarang. The sample was divided into 28 elderly intervention groups and 28 elderly control groups. Data were analyzed using Wilcoxon Signed Rank test. The result of the research showed that in the intervention group the p-value value is 0.001 (less than $\alpha 0.05$ ) with the percentage of $65 \%$, whereas in the control group the p-value value is 0.157 (greater than $\alpha 0.05$ ) with the percentage of $9.99 \%$. In conclusion, music therapy rebana can improve the quality of sleep in the elderly with high success.
\end{abstract}

Keywords: Rebana music, Sleep quality, Elderly

\begin{abstract}
Abstrak: Terapi Musik Rebana Mampu Meningkatkan Kualitas Tidur Lansia. Tidur merupakan kebutuhan dasar manusia yang harus dipenuhi. Kebutuhan tidur pada lansia berkisar 56 jam per hari. Namun perubahan kondisi tubuh, masalah kesehatan fisik dan psikologis menyebabkan lansia beresiko mengalami gangguan tidur. Intervensi non farmakologis untuk mengatasi gangguan tidur pada lansia salah satunya dengan menggunakan musik rebana. Penggunaan musik rebana sebagai terapi mirip dengan terapi occupational dan fisik, mampu merangsang tubuh untuk melepaskan epineprin dan norepineprin yang membuat tubuh menjadi rileks. Kondisi rileks ini akan meningkatkan kualitas tidur lansia. Tujuan penelitian ini untuk membuktikan penggunaan musik rebana sebagai terapi yang mampu meningkatkan kualitas tidur padalansia. Metode penelitian ini merupakan quasi eksperimen dengan desain non equivalent control group. Sampel penelitian ini sebanyak 56 lansia yang tinggal di Unit Pelayanan Sosial Lanjut Usia Pucang Gading Semarang. Sampel dibagi menjadi 28 lansia kelompok intervensi dan 28 lansia kelompok kontrol. Analisis data menggunakan Wilcoxon Signed Rank test. Hasil penelitian menunjukkan pada kelompok intervensi nilai $p$-value sebesar 0,001 (lebih kecil dari $\alpha$ 0,05 ) dengan prosentase $65 \%$, sedangkan pada kelompok kontrol nilai p-value sebesar 0,157 (lebih besar dari $\alpha$ 0,05) dengan prosentase 9,99\%. Kesimpulannya, Terapi musik rebana mampu meningkatkan kualitas tidur pada lanjut usia dengan keberhasilan tinggi.
\end{abstract}

Kata kunci: Musik rebana, Kualitas tidur, Lansia

Tidur merupakan salah satu kebutuhan dasar manusia yang termasuk kedalam kebutuhan fisiologis. Tidur sangat dibutuhkan bagi setiap orang yang hidup di dunia, karena sangat penting bagi kualitas hidup semua orang. Kebutuhan tidur setiap orang akan berbeda-beda, pada lanjut usia membutuhkan durasi tidur 5-6 jam per hari (National Sleep Foundation, 2007). Namun karena kondisi tubuhnya sebagian besar lansia berisiko tinggi mengalami gangguan tidur yang khas, gangguan tersebut mencakup kebiasaan tidur, terbangun pada dini hari, peningkatan waktu tidur pada siang hari dan membutuhkan waktu lebih lama untuk dapat memulai tidur (George, Z., 2008).

Prevalensi gangguan tidur pada lansia cukup tinggi yaitu sekitar 40-50\%, sekitar $19 \%$ lansia mengalami kesulitan tidur, $21 \%$ tidur terlalu sedikit, 24\% kesulitan tidur sedikitnya 1 kali seminggu, dan 39\% mengantuk berlebihan di siang hari (American Insomnia Association, 2002). Gangguan tidur yang berkepanjangan mengakibatkan penurunan kualitas tidur (Silvanasari, 2013), yang akan berpengaruh pada 
perubahan-perubahan siklus tidur biologiknya, daya tahan tubuh menurun, prestasi kerja menurun, mudah tersinggung, depresi, kurang konsentrasi dan kelelahan. Kualitas tidur yang buruk pada lansia terutama dipengaruhi oleh masalah psikologis (stres dan kecemasan) (Silvanasari, 2013; Liambo, Zulaikha, \& luthfa, 2014).

Stres dan kecemasan merupakan masalah psikologis yang sering dialami oleh lansia. Seseorang yang mengalami stres dapat menyebabkan perubahan pola tidur, kesulitan mulai tidur, masuk tidur memerlukan waktu lebih dari 60 menit, timbulnya mimpi yang menakutkan, mengalami kesulitan untuk bangun pagi hari, dan merasa badan tidak segar ketika bangun (Rafknowledge, 2004).

Selama ini intervensi yang sering dipakai untuk mengatasi masalah gangguan psikologis pada lansia dengan penggunaan obat-obatan (antidepresan), namun penggunaan obat ini memiliki efek samping seperti mual, muntah dsb. Penggunaan jangka panjang pun tidak dianjurkan karena memiliki efek yang dapat menyebabkan masalah kesehatan lainnya (iatrogenesis) termasuk menyebabkan insomnia, kondisi ini justru menyebabkan lansia mengalami gangguan tidur yang lebih parah. Hal ini tentunya diperlukan intervensi lain yang tidak membahayakan kesehatan lansia.

Hasil penelitian terdahulu yag pernah dilakukan membuktikan bahwa masalah psikologis (stres) dapat diturunkan melalui terapi musik rebana (Luthfa, Sari, \& Khasanah, 2015). Musik rebana merupakan musik yang bercirikan islam, dengan nuansa sastra yang berisi rasa syukur kepada Allah SWT dan puji-pujian terhadap Nabi Muhammad SAW. Penggunaan musik rebana sebagai terapi mirip dengan terapi occupational dan fisik. Musik rebana merupakan terapi non invasiv yang mampu merangsang penurunan hormon kortisol yang dihilangkan pada saat stres, dan meningkatkan pelepasan epineprine. Ketika tubuh dalam kondisi cemas ataupun stres, dengan mendengarkan musik rebana maka tubuh akan melepaskan epineprin dan norepineprin yang mengakibatkan tubuh menjadi rileks. Kondisi rileks ini akan meningkatkan kualitas tidur pada lansia.

\section{METODE}

Penelitian ini dilakukan di Unit Pelayanan Sosial Pucang Gading Semarang. Rancangan penelitian menggunakan quasi eksperiment dengan desain non equivalent control group (Maltby, William, McGarry \& Day, 2010). Jumlah populasi sebanyak 85 orang, dengan sampel sebanyak 56 responden yang dibagi menjadi dua kelompok, yaitu 28 lansia kelompok intervensi dan 28 lansia kelompok kontrol. Besar sampel diambil menggunakan rumus sample size, dengan teknik purposive sampling (Polit and Beck, 2006). Sampel yang diambil memiliki criteria berusia $>45$ tahun, sudah tinggal di Unit Pelayanan Sosial minimal 1 tahun dan mengalami gangguan tidur minimal 1 minggu terakhir.

Kelompok intervensi diberikan terapi musik rebana sebanyak 4 kali, masing-masing terapi diberikan selama 60 menit. Untuk kelompok kontrol tidak diberikan intervensi apapun. Alat yang digunakan untuk terapi musik rebana menggunakan satu set rebana terdiri dari: 4 rembang, 7 tamborin, 3 jedorbesar, 2 bongo dan 8 icik-icik. Instrument penelitian untuk mengukur kualitas tidur menggunakan Pittsburgh Sleep Quality Index (PSQI).

Data kualitas tidur diambil pada saat pre intervensi dan post intervensi. Analisis data menggunakan Wilcoxon Signed Rank Test dengan derajat kemaknaan $\alpha<0,05$.

\section{HASIL}

\section{KarakteristikResponden}

Tabel 1. Distribusi Frekuensi Karakteristik Responden

\begin{tabular}{lrrrr}
\hline \multirow{2}{*}{ Variabel } & \multicolumn{2}{c}{$\begin{array}{c}\text { Intervensi } \\
(\mathbf{n = 2 8})\end{array}$} & \multicolumn{2}{c}{$\begin{array}{c}\text { Kontrol } \\
(\mathbf{n = 2 8})\end{array}$} \\
\cline { 2 - 5 } & $\mathbf{f}$ & $\mathbf{( \% )}$ & \multicolumn{1}{c}{$\mathbf{F}$} & $\mathbf{( \% )}$ \\
\hline Usia responden & & & & \\
$45-54$ & 7 & 25,0 & 9 & 32,1 \\
$55-64$ & 13 & 46,4 & 10 & 35,7 \\
$>$ 65 & 8 & 28,8 & 9 & 32,1 \\
\hline Jenis kelamin & & & & \\
Laki-laki & 14 & 50,0 & 12 & 42,9 \\
Perempuan & 14 & 50,0 & 16 & 57,1 \\
\hline
\end{tabular}

\section{Kualitas Tidur Lanjut Usia}

Tabel 2. Distribusi Frekuensi Kualitas Tidur Responden

\begin{tabular}{lrrrr}
\hline Kelompok & \multicolumn{2}{c}{ Pre Test } & \multicolumn{2}{c}{ Post Test } \\
& \multicolumn{1}{c}{ KualitasTidur } & \multicolumn{2}{c}{ KualitasTidur } \\
\cline { 2 - 5 } Baik & Buruk & \multicolumn{1}{c}{ Baik } & Buruk \\
\hline Intervensi & 8 & 20 & 21 & 7 \\
& $(28,6 \%)$ & $(71,4 \%)$ & $(75,0 \%)$ & $(25,0 \%)$ \\
\hline Kontrol & 8 & 20 & 10 & 18 \\
& $(28,6 \%)$ & $(71,4 \%)$ & $(35,7 \%)$ & $(64,3 \%)$ \\
\hline
\end{tabular}




\section{Hasil Uji Wilcoxon Signed Rank Test}

Tabel 3. Perbedaan Rata-rata Kualitas Tidur Sebelum dan Sesudah Pemberian Musik Rebana

\begin{tabular}{lllccccc}
\hline Kelompok & \multicolumn{1}{c}{ Data } & Mean & Mean Selisih & Z tabel $(\mathbf{\alpha}$. 5\%) & Z Hitung & $\boldsymbol{p}$ \\
\hline \multirow{2}{*}{ Intervensi } & Pre Test & 0,7143 & 0,4643 & 1,96 & $-3,357$ & 0,001 \\
\cline { 2 - 5 } & Post Test & 0,2500 & & & & \\
\hline \multirow{2}{*}{ Kontrol } & Pre Test & 0,7143 & 0,0714 & 1,96 & $-1,414$ & 0,157 \\
\cline { 2 - 3 } & Post Test & 0,6429 & & & & \\
\hline
\end{tabular}

\section{PEMBAHASAN}

Tidur didefinisikan sebagai suatu keadaan bawah sadar dimana seseorang masih dapat dibangunkan dengan pemberian rangsang sensorik atau dengan rangsang lainnya (Guyton \& Hall, 2006). Tidur merupakan kebutuhan setiap manusia, karena sebagai cara untuk meningkatkan kesegaran tubuh setelah lelah beraktivitas. Tidur juga bermanfaat untuk pemeliharaan kesehatan, karena pada saat tidur tubuh melakukan regenerasi sel sehingga membantu proses penyembuhan penyakit.

Secara umum tidur dibagi menjadi dua tahap yaitu (1) Tahap satu Non Rapid Eye Movement (NREM), NREM adalah tahap tidur yang tenang ditandai denyut jantung dan frekuensi pernafasan yang stabil dan lambat, serta tekanan darah yang rendah. NREM dibagi menjadi 4 stadium yaitu: Stadium 1 merupakan fase transisi antara kondisi sadar dan tertidur berlangsung sekitar 5 menit, ditandai dengan mata bergerak lambat, aktivitas otot menurun, dan mudah terbangun. Stadium 2 merupakan fase tidur pada tahap yang lebih dalam, ditandai dengan detak jantung mulai melambat, pergerakan bola mata terhenti, dan berlangsung antara 10 sampai 30 menit. Stadium 3 dan 4 merupakan fase tidur pada tahap yang paling dalam dari tidur NREM, seseorang yang memasuki tahap ini akan sulit untuk dibangunkan, tidak ada aktivitas dari mata dan otot, kedua tahapan ini berlangsung selama 30 sampai 40 menit.

Setelah berada di stadium 4, sikus tidur akan berulang kembali ke stadium sebelumnya yaitu 3 dan 2, akhirnya akan masuk ke tahap tidur yang kedua yaitu Rapid Eye Movement (REM). REM merupakan tahap tidur yang sangat dalam, seseorang yang berada pada tahap ini bisa merasakan mimpi yang tampak nyata (lucid dream). REM berlangsung sekitar 70-90 menit. Siklus tidur normal pada lansia umumnya mengikuti pola berikut: kondisi sadar, stadium 1, 2, 3, 4, 3, 2, REM, dan bangun tidur.

Kebutuhan istirahat tidur pada lansia berbeda dengan usia dewasa, lansia membutuhkan tidur sekitar 6 jam setiap harinya. Namun karena kondisi fisik dan psikologis lansia sering mengeluh tidak bisa tidur nyenyak, episode tidur cenderung lebih singkat karena sering terbangun ketika tidur, dan memerlukan lebih banyak waktu untuk dapat tertidur kembali. Gangguan tidur pada lansia menurut Fitri (2009) prevalensinya cukup tinggi yaitu sekitar $67 \%$. Hasil penelitian juga menunjukkan bahwa, data awal sebelum diberikan intervensi dari 56 responden sebanyak 40 lansia $(71,4 \%)$ mengalami gangguan pola tidur sehingga memiliki kualitas tidur yang buruk.

Gangguan tidur sering disebabkan karena masalah psikologis yaitu perasaan cemas dan stres karena pemenuhan kebutuhan hidup yang kurang (Ernawati \& Sudaryanto, 2010). Hal ini sesuai dengan hasil penelitian terdahulu yang menunjukkan bahwa adanya hubungan antara kecemasan lansia dengan kecenderungan insomnia (Wiyono, 2009; Sohat, Bidjuani \& Kallo, 2014). Gangguan tidur pada lansia yang berkepanjangan akan mengakibatkan penurunan kualitas tidurnya yang akan berpengaruh terhadap kesehatan fisik, kemampuan kognitif dan juga kualitas hidup.

Lansia yang berada dalam kondisi cemas dan stres, maka tubuhnya akan mengalami perubahan fisiologis yaitu terjadinya peningkatan kerja pada organ jantung (denyut jantung meningkat), penyempitan pembuluh darah, peningkatan tekanan darah, organ paru meningkat (pernafasan meningkat) dan sebagainya (Hunter \& Gillen, 2009), kondisi seperti ini akan berpengaruh pada kualitas tidur lansia.

Intervensi untuk meningkatkan kualitas tidur pada lansia adalah dengan menghilangkan faktor penyebab yaitu mengatasi masalah psikologis pada lansia (stres dan kecemasan). Penelitian terdahulu sudah membuktikan bahwa stres dan cemas pada lansia dapat diturunkan dengan menggunakan terapi musik rebana (Luthfa, Sari, \& Khasanah, 2015). Penggunaan musik untuk menurunkan tingkat kecemasan dan stres sudah banyak dibuktikan oleh beberapa penelitian, antara lain musik mampu menurunkan 
tingkat kecemasan pada pasien perioperative osteoarthritis (Ottaviani, Jean-Luc, Thomas \& Pascal, 2012); musik memberikan efek positif terhadap tekanan darah, denyut jantung, pernafasan, kecemasan dan rasa sakit pada pasien yang memiliki penyakit jantung koroner sehingga mampu meningkatkan relaksasi yang berdampak pada penurunan tingkat kecemasan selama sakit (Dileo, 2009), musik dapat menurunkan stres pada pasien yang menjalani prosedur kolonoskopi (Bechtold, Puli, Othman, Bartalos, Marshall \& Roy, 2009), dan musik sudah digunakan dalam management stres (Gao, 2007).

Berdasarkan penelitian sebelumnya penggunaan musik untuk mengatasi gangguan tidur sudah dibuktikan keberhasilannya. Nursalam dkk (2014) menggunakan musik langgam jawa untuk membantu memenuhi kebutuhan tidur pada lansia di Panti Werdha Blitar, hasilnya menunjukkan keberhasilan dengan nilai $p$-value sebesar 0,000. Sahanantya, Armiyati dan Arif (2014) menggunakan musik klasik Mozart untuk meningkatkan kualitas tidur pada pasien stroke di RS, hasilnya menunjukkan keberhasilan dengan nilai p-value 0,000 . Astriawan (2016) menggunakan musik instrumental kitaro untuk mengatasi gangguan tidur pada pasien rawat inap, dan menunjukkan keberhasilan dengan nilai $p$-value sebesar 0,000.

Terapi musik memiliki efek yang berbedabeda pada setiap orang, namun yang dipilih sebagai terapi untuk mengatasi gangguan tidur pada lansia sebaiknya musik yang mendorong relaksasi, perasaan bergairah dan damai. Dalam hal ini musik yang dipilih adalah musik rebana.

Hal ini sesuai dengan hasil penelitian yang telah dilakukan, pada tabel 3 memperlihatkan perbedaan rata-rata kualitas tidur sebelum dan sesudah pemberian musik rebana pada kelompok intervensi dan kelompok kontrol, hasilnya pada kelompok yang diberi intervensi musik rebana menunjukkan peningkatan kualitas tidur yang cukup signifikan dengan nilai $p$-value 0,001 $(<0,05)$ dan nilai selisih meannya 0,4643 .

Sedangkan pada kelompok kontrol (kelompok yang tidak diberikan intervensi), tabel 3 memperlihatkan bahwa kualitas tidur lanjut usia yang tidak diberi intervensi musik rebana menunjukkan tidak ada perubahan kualitas tidur dengan nilai $p$-value $0,0714(>0,05)$ dan nilai selisih mean 1,96.

Musik rebana adalah jenis musik berasal dari budaya arab, yang diperkirakan berkembang di Jawa sekitar abad XVI dibawa oleh para wali dan penyebar agama islam di Indonesia, selanjutnya berakulturasi dengan budaya lokal (Susetyo, 2007). Permainan musik rebana sering dipentaskan dalam peristiwa-peristiwa yang bersifat ritual.

Musik rebana merupakan musik yang bertemakan islami berisi puji-pujian kepada Allah SWT dan Nabi Muhammad SAW, hal ini sesuai dengan teori penuaan bahwa ketenangan batin (perasaan damai) lansia dipengaruhi oleh terpenuhinya kebutuhan spiritual.

Terapi musik rebana merupakan suatu layanan kesehatan yang mirip dengan terapi occupational dan fisik. Terapi musik masuk melalui stimulus intelektual di dalam otak dan langsung berpindah kealam bawah sadar, mampu meningkatkan hormon endorphin dan menurunkan hormon epineprin yang mampu mempengaruhi fungsi fisiologis seperti pernafasan, detak jantung dan tekanan darah. Kondisi ini menyebabkan lansia akan merasa lebih rileks dan nyaman dalam tidurnya (Potter \& Perry, 2007).

Terapi musik rebana identik dengan kemeriahan musik, karena dimainkan dengan iringan terbang dan dinyanyikan secara bersamasama, hal ini meningkatkan semangat hidup dan sosialisasi. Menurut Djohan (2009) musik dapat digunakan untuk memenuhi kebutuhan interaksi sosial melalui aktivitas kelompok musik yang berorientasi pada kesenangan secara emosional.

Terapi musik rebana memerlukan kepiawaian semua pemainnya untuk bersamasama memadukan bunyi pukulan gendang antara DUNG dan TAK, sehingga terdengar lebih kompak dan ramai. Menurut Setiadarma (2009) salah satu manfaat musik sebagai terapi adalah self-mastery yaitu kemampuan mngendalikan diri. Musik mengandung vibrasi energi yang mampu mengaktifkan sel untuk meningkatkan system kekebalan di dalam tubuh, meningkatkan serotonin untuk menurunkan hormon ACTH (hormon stres).

\section{SIMPULAN}

Hasil uji pada kelompok intervensi didapatkan nilai $\mathrm{Z}$ hitung sebesar -3,357 (lebih kecil dari nilai $\mathrm{Z}$ table sebesar 1,96 ), dan nilai $\mathrm{p}$ value sebesar 0,001 (lebih kecil dari $\alpha$ 0,05). Hal ini menunjukkan musik rebana mampu meningkatkan kualitas tidur pada lanjut usia.

Hasil uji pada kelompok kontrol didapatkan nilai $Z$ hitung sebesar -1,414 (lebih kecil dari nilai $\mathrm{Z}$ table sebesar 1,96$)$, dan nilai $p$ value sebesar 0,157 (lebih besar dari $\alpha 0,05$ ). Hal ini menunjukkan kelompok kontrol yang tidak diberikan intervensi maka kualitas tidur lansia tidak mengalami peningkatan. 


\section{SARAN}

Hasil penelitian ini menunjukkan bahwa ada terapi yang secara non farmakologis dapat diaplikasikan untuk menangani gangguan tidur pada lanjut usia sehingga kualitas tidurnya

\section{DAFTAR PUSTAKA}

American Insomnia Association. 2012. American Insomnia Association Treatment. http://www.americaninsomniaassociation.o rg (Diakses 17 april 2016).

Astriawan, E. 2016. Pengaruh musik instrumental kitaro terhadap kualitas tidur pasien rawat inap yang mengalami gangguan tidur di RSUD Ungaran. Skripsi. PSIK STIKES Ngudi Waluyo Ungaran. perpusnwu.web.id/karyailmiah/documents/ 4751

Bechtold, M.L., Puli, S.R., Othman, M.O., Bartalos, C.R., Marshall, J.B, and Roy, P.K. 2009. Effect of music on patients undergoing colonoscopy: a meta-analysis of randomized controlled trials. Dig Dis Sci, 54(1):19-24

Dileo. 2009. Music for Stress and Anxiety Reduction in Coronary Heart Disease Patients. Cochrane Database Syst Rev (2): CD006577.

Djohan, 2009. Terapi Musik Teori dan Aplikasi.Yogyakarta: Galangpress.

Ernawati \& Sudaryanto. 2010. Faktor-faktor yang Berhubungan dengan Terjadinya Insomnia pada Lanjut Usia di Desa Gayam Kecamatan Sukoharjo. Berita Ilmu Keperawatan, Vol. 3 No.2, Juni 2010.

Fitri, M.Y. 2009. Gangguan Tidur Pada Lansia. http//stikeskabmalang.wordpress.com

Gao. 2007. Managing Stress with Music: Issues in Research. Australian Journal of Music Education.

George, Z. 2008. Differential Diagnosis and Evaluation of Sleepiness. Fishman's Pulmonary Diseases and Disorders, 4th edition. New York: McGraw-Hill, 172734.

Guyton, \& Hall, d. 2006. Differential Diagnosis and Evaluation of Sleepiness. Fishman's Pulmonary Diseases and Disorders, 4th edition. New York: McGraw-Hill, 172734.

Hunter \&Gillen. 2009. Stress Coping Mechanism in Elderly Adults: an Initial Study of Recreational and Other Coping Behaviors in Nursing Home Patients. mengalami peningkatan yaitu dengan menggunakan musik rebana. Hasil penelitian ini dapat dikembangkan melalui penelitian lanjutan, yang diarahkan untuk mencapai tujuan jangka panjang yaitu peningkatan kualitas hidup lanjut usia.

Luthfa, Sari, \& Khasanah, D. 2015. Pengaruh Musik Rebana terhadap Tingkat Penurunan Stres pada Lansia yang di Rawat di Panti Wredha Pucang Gading Semarang. Nurscope. Volume 1 tahun 2015. ISSN. 2476-8987.

Maltby, William, McGarry \& Day. 2010. Research Methods for Nursing and Healthcare. www.personed.co.uk. ISBN 9780273718505.

National Sleep Foundation. 2007. How much sleep do we really need?. http://www.sleepfoundation.org (Diakses pada 17 april 2016).

Nursalam, Haryanto, J,. Indarwati, R. \& Wahyuni, E.D. 2014. Musik Langgam Jawa dalam Upaya Pemenuhan Kebutuhan Tidur Lansia. https://media.neliti.com/media/publications /116629-ID.

Ottaviani, Jean-Luc, Thomas, \& Pascal. 2012. Effect of Music on Anxiety and Pain During Joint Lavage for Knee Osteoarthritis. Clin Rheumatol. DOI 10.1007/s10067-011-1925-9.

Polit, D F., \& Beck, C.T. 2006. Essentials of Nursing Research: Methods, appraisal, and utilization (6th ed). Philadelphia: Lippincot Williams \& Walkims.

Potter \& Perry, 2007. Buku Ajar Fundamental Nursing. Konsep, Proses dan Praktik. Jakarta: EGC

Rafknowledge. 2014. Insomnia dan Gangguan Tidur Lainnya. Jakarta: PT Elex Media Komputindo.

Sahanantya, A.R., Armiyati, Y, dan Arif, S. 2014. Pengaruh Terapi Musik Klasik Mozart terhadap Kualitas Tidur pada Pasien Stroke di Rumah Sakit Pantiwilasa Citarum Semarang. Karya Ilmiah S.1 Keperawatan, STIKES Telogorejo. http://ejournal.stikestelogorejo.ac.id/index. php/ilmukeperawatan/article/view/256

Setiadarma, 2009. Cerdas dengan Musik. Jakarta: Pustaka Swara.

Silvanasari. 2013. Faktor-faktor yang Berhubungan dengan Kualitas Tidur yang 
Buruk pada Lansia di Desa Wonojati Kecamatan Jenggawah Kabupaten Jember. Universitas Jember. Skripsi, Prodi Keperawatan, Universitas Jember. http://repository.unej.ac.id/handle/1234567 $89 / 3229$.
Wiyono, W. 2009. Hubungan Antara Tingkat Kecemasan dengan Kecenderungan Insomnia pada Lansia di Panti Wredha Dharma Bakti Surakarta. Skripsi, Fakultas Ilmu Kesehatan, Universitas Muhammadiyah Surakarta. 